\title{
Role of Education in Women Empowerment and Entrepreneurship
}

\author{
Deepa Indoria*, Mani Ram and R.L. Solanki \\ Krishi Vigyan Kendra, Chittorgarh, Krishi Vigyan Kendra, Rajsamand, \\ MPUAT, Udaipur, India \\ *Corresponding author
}

\section{A B S T R A C T}

\begin{tabular}{|l|l|l|}
\hline Keywords & $\begin{array}{l}\text { The capacity and willingness to develop organize and manage a business venture along } \\
\text { with any of its risks in order to make a profit. The most obvious example of } \\
\text { entrepreneurship is the starting of new businesses. In economics, entrepreneurship } \\
\text { combined with land, labour, natural resources and capital can produce profit. }\end{array}$ \\
$\begin{array}{l}\text { Entrepreneurship, } \\
\text { empowen }\end{array}$ & $\begin{array}{l}\text { Entrepreneurial spirit is characterized by innovation and risk-taking, and is an essential } \\
\text { part of a nation's ability to succeed in an ever changing and increasingly competitive } \\
\text { global market place. Entrepreneurship is the act of being an entrepreneur, which can be } \\
\text { define as "one who undertakes innovations, finance, and business acumen, in an effort to } \\
\text { transform innovations, into economic goods. Women entrepreneurial development is one } \\
\text { Article Info }\end{array}$ & $\begin{array}{l}\text { Accepted: } \\
\text { 04 April } 2019\end{array}$ \\
$\begin{array}{ll}\text { Available Online important area majority countries has been focus upon as a part of over all Human } \\
10 \text { May } 2019\end{array}$ &
\end{tabular}

\section{Introduction}

Entrepreneurship is the act of being an entrepreneur, which can be define as "one who undertakes innovations, finance, and business acumen, in an effort to transform innovations, into economic goods. Entrepreneurship means small business owners opening up their shop doors on Main Street $(1,2)$. Ultimately, entrepreneurship encompasses these and many other business ventures that share a commitment to turning an idea into a profitable business. Women entrepreneurial development is one of the important area majority countries has been focus upon as a part of over all human resource development. It is well ascertained by policy makers across the courtiers that strategic development of an economy required equal participation and equal opportunities to all sect and genders. Entrepreneurial development is one the significant factor for sustainable socio-economic development $(3,4)$. Especially, development of women is inviting special significance because many small and medium firms are well operated through women and though it is less recognized. How rural women looks on entrepreneurial opportunities and what are their concerns to enter into such ventures? 
This particular research tries to understand the motivational factors of women which influence on entrepreneurial factors, and how it facilitate the educators and educational institutions to develop infrastructure, design programs and course ware, ensure training and development. Activities that in tune with the requirement of entrepreneurial education in rural and semi urban areas where small and medium scale industries are more located (57). Women entrepreneurship has been recognised as an important source of economic growth. Women entrepreneurs create new jobs for themselves and others and also provide society with different solutions to management, organisation and business problems. However, they still represent a minority of all entrepreneurs. Women entrepreneurs often face gender based barriers to starting and growing their businesses, like discriminatory property, matrimonial and inheritance laws and/or cultural practices; lack of access to formal finance mechanisms; limited mobility and access to information and networks, etc. Earlier it prepared an individual obtain recent scientific information to cope with the day to day problems but today efforts are being made to provide facilities to invigorate the theoretical knowledge of the students through field training and research laboratories so that they are able to launch entrepreneurship programmes successfully. Despite the contributions to family and society, women still do not have equal access to rights, services and opportunities i.e. equal pay and decent work, property and inheritance rights, access and control of land including financial services and credit. All this requires raising awareness among policy makers about the relevant gender aspects of different policy areas, such as - taxation, public budgets and employment.

To respond to these deep-rooted problems, UNDP in partnership with other UN agencies and development partners works to support national governments to develop genderresponsive economic plans, policies and social protection systems. This includes supporting measures to reduce women's unpaid work, initiatives to ensure women's equal access to decent employment opportunities, resources and finance, and helping to develop and implement gendersensitive budget processes (8-10).

\section{Food and nutrition studies}

Food and Nutrition deals with nature of food; the constituents of food; food required for the growth and maintenance of body functions; food needs at the different stages of life; nutrimental deficiencies and ways of overcoming them; preparation of food in a way so as to conserve the maximum nutritive value and preserve its flavour; the biochemical changes that food undergo during digestion; preservation of food and food habits. The studies in this field objectively prepare the students to work in any of the following enterprises (11-12):

\section{Catering}

Catering could be provided to fulfil needs of the society. Service could be extended for parties arranged at home such as kitty parties, birthday parties or anniversary parties etc. Catering could be made at special places like school and hospitals. Besides these, it will be very useful in running canteen in various types of settings. The trained professionals can also undertake catering services for people who are working in factories, offices and do not have time or arrangement to cook meals, particularly unit days meals.

\section{Confectionery and bakery}

The Special studies graduates / postgraduates can set up confectionery, ice-cream Parlors 
and Bakery. They can use innovation skill to evolve their own products which are more nutritive and different from the conventional ones and add variety at parties or at dining table.

\section{Preservation}

Preservations of vegetables and fruits in the form of pickles, jams, jellies, marmalades etc. could be undertaken. The need to buy these preserves from the market would definitely increase keeping in mind the availability of time with women who traditionally were busy doing the work at home (13).

\section{Ready to cook/serve food}

Small units could be established to clean/cut/shell the vegetables so as to make these ready for cooking by the house wife. A variety of salads could be prepared to set up salad bar along with fast food to promote healthy living.

\section{Health centres}

Health Centre could provide special advice for the dietary needs of people suffering from different diseases. Suitable therapeutic nutrition and physical education would enable the special studies graduate to set up support centres for people with special dietary needs. Guidance could be given to the individuals for keeping fit through diet and exercise and management of obesity and related conditions.

\section{Hobby centres}

Hobby Centres could be started to train interested people in various culinary art of different regions and continents. Graduates / Post-Graduates can seek jobs as Dieticians in hospitals, nursing homes and fitness centres; else become Nutrition Counsellors and
Nutrition Experts in national/ international agencies like ICMR, NIN, CARE, WFP, UNICEF, CRY, Chetna etc. Food technologists and researchers entrepreneurs offering health and nutrition consultancy services; in mass media industry as Nutrition Journalists. They can join catering organizations, food processing industry else opt for teaching and research (14-16).

\section{Resource management}

Resource Management undertakes the study of managing the home economically and effectively. The home implies the basic facts about housing designs, furnishing which will save money and labour and methods of getting the maximum work done through the minimum equipment. Management of home in making the best use of the available resources, to derive the best value to conserve time, energy, money, space and labour. The home-maker must plan wisely to provide out of the available resources, the best possible food, clothing, shelter, health, education and recreation for the members of the family. Special studies graduate / postgraduates acquire sufficient management skill to open guidance centres where they can impart training in the following listed fields of entrepreneurship (17-20).

\section{Interior designing}

They can impart training in the art of interior decoration. Such centres can also provide services for decoration of various settings like offices, hospitals, school.

\section{Hobby centres}

Hobby Centres could be started where interested persons could learn candle and paper flower making, preparation of decorative articles, soft toys, Rangoli, jewellery designing, pot making, wall 
painting and making useful articles from the household waste products (21-22).

\section{Grooming centres}

This area has vast potential to develop among masses. Training could be imparted under education to open grooming centres where they could provide services for skin and hair care. The individualized guidance could be extended according to the unique characteristics to select jewellery, hair style and face make up.

\section{Fabric and apparel designing}

This domain of special studies focus on the selection, construction and care of clothing; its effect on the family income; the behaviour and chemical nature of different textiles; types of weaves; the quality, colour, shrink ability and durability of fabrics; quality of natural fibres like silk, wool, cotton, nature of synthetic fibres like nylon, rayon, Teri-cot etc.

Special studies graduate / postgraduates acquire sufficient management skill to open their own centres where they can impart training in the following listed fields of entrepreneurship.

a) Boutique.

b) Dyeing and Printing unit

c) Readymade Garment unit.

d) Embroidery centre

e) Weaving unit.

\section{Human development}

Human Development enriches emotional relationship among family members. The most important amongst a family are the children. They must be brought up in an atmosphere conducive to growth and development. Children must be given strength of character to meet the challenges of their later life by their parents and other family members.

\section{Child care centres}

Women participating in income generation actively outside the home had led to the need of child care outside the family. Children usually require care by adults till they are 12 year of age and should not be left alone at home with the basic knowledge of child development, the Special studies graduates can run childhood care units like day-care centre, crches, and nursery school and after school centres.

\section{Old age homes}

Increase in the nuclearization of families has compelled many old people to stay in old age homes away from their families. Such old age home can be managed by Special studies graduates where various kinds of activities could be arranged for old people with proper food services and psycho-emotional enrichment (23-25).

\section{Rehabilitation centres for children with special needs}

Special studies graduate can open rehabilitation centres for children with impaired senses. These centres will not only be a service to the community but would help them create employment for themselves and others. Gradates / Post Graduates can take up jobs as Counsellors, Teachers, Education Officers, Researchers or can develop programmes

\section{Opportunities for self- employment/entrepreneurship:}

Producer of household craft items, decorative articles and creative items

Owner of a nursery school, day care centre, crèche, balwadi

Owner of a guest house or paying guest accommodation Tailor and/or finisher for 
stitched garments, e.g., sewing buttons, doing hemming or attaching a fall on sari etc

Owner of boutique, knitted garment unit, weaving unit and fabric enrichment unit

Owner of dry cleaning shop - Owner of a canteen Supplier of packed meals and food service from home

Owner of bakery, processed and preserved foods

Manager of outdoor catering service for parties

Conducting classes in cooking, garment construction, fabric enrichment, soft toy making, knitting, weaving, etc.

Packaging gift articles, selling fresh and dry flower arrangements, contractual services for decoration for parties - Writer of articles for children's/ women's magazines

\section{Policies and schemes for women entrepreneurs in India}

Women are key contributors to economies as producers of food, managers of natural resources, caretakers of children and the elderly, entrepreneurs and employees in businesses, and as significant contributors to building resilience of communities to climate change and disaster. In India, the Micro, Small and Medium Enterprises development organisations, various State Small Industries Development Corporations, the Nationalised banks and even NGOs are conducting various programmes including Entrepreneurship Development Programmes (EDPs) to cater to the needs of potential women entrepreneurs, who may not have adequate educational background and skills.

The Office of DC (MSME) has also opened a Women Cell to provide coordination and assistance to women entrepreneurs facing specific problems. There are also several other schemes of the government at central and state level, which provide assistance for setting up training-cum-income generating activities for needy women to make them economically independent. Small Industries Development Bank of India (SIDBI) has also been implementing special schemes for women entrepreneurs. In addition to the special schemes for women entrepreneurs, various government schemes for MSMEs also provide certain special incentives and concessions for women entrepreneurs. For instance, under Prime Minister's Rozgar Yojana (PMRY), preference is given to women beneficiaries. The government has also made several relaxations for women to facilitate the participation of women beneficiaries in this scheme. Similarly, under the MSE Cluster Development Programme by Ministry of MSME, the contribution from the Ministry of MSME varies between $30-80 \%$ of the total project in case of hard intervention, but in the case of clusters owned and managed by women entrepreneurs, contribution of the M/o MSME could be up to $90 \%$ of the project cost. Similarly, under the Credit Guarantee Fund Scheme for Micro and Small Enterprises, the guarantee cover is generally available up to $75 \%$ of the loans extended; however the extent of guarantee cover is $80 \%$ for MSEs operated and or owned by women (26-28).

Women entrepreneurs in the four southern states and Maharashtra account for over 50\% of all women-led small-scale industrial units in India.

Women entrepreneur associations: The efforts of government and its different agencies are supplemented by NGOs and associations that are playing an equally important role in facilitating women empowerment. List of various women associations in India is provided below.

Details of women entrepreneur associations in India 
S.No. Association name Website

1. Federation of Indian Women Entrepreneurs (FIWE) http://www.fiwe.org/

2. Consortium of Women

Entrepreneurs(CWEI) http://www.cwei.org/

3. Association of Lady Entrepreneurs of Andhra Pradesh http://www.aleap.org/index.html

4. Association of Women Entrepreneurs of Karnataka (AWAKE) http://awakeindia.org.in/

5. Self-Employed Women's Association (SEWA) http://www.sewa.org/

6. Bihar Mahila Udyog SanghBihar Mahila Udyog Sangh http://www.biharmahilaudyogsangh.com/

7. Mahakaushal Association of Woman Entrepreneurs (MAWE) http://www.maweindia.com/

8. SAARC Chamber Women Entrepreneurship Council http://www.scwec.com/index.htm

9. TiE Stree Shakti (TSS) http://www.tiestreeshakti.org/

10. Women Empowerment Corporation http://www.wecindia.org

In conclusion, special studies have contributed a great deal towards national development by training students to take up leadership roles in extension and community outreach programs. The students are encouraged to develop a scientific temper. Familiarizing them with the use of newer technologies, methods in family and community linkages, and sustainable use of resources for human development are the hall mark of education in Special studies. As a discipline Special studies integrates the ingredients of the sciences, social sciences and technology to facilitate the study of and enhance the quality of human life. Its approach is therefore inherently interdisciplinary. Traditionally, Special studies have adopted an ecological approach in its curriculum that engages the student through teaching, research and extension. The education process in Special studies underscores the importance of the individual's dynamic relationship with his/her family, community and society as a whole, as well as with the resources in the environment. Higher education learning in Special studies subjects provides students the opportunity to sharpen their capacities with a sense of social responsibility. Years of national and international experience in the field has contributed to the wisdom that all the five windows of opportunity that Special studies offers be opened for i.e. Food and Nutrition, Human Development and Childhood Studies, Resource Management and Design Application, Development Communication and Extension and Fabric and Apparel Sciences. In this course, the students will learn the fundamental principles and foundations of all the five areas. They are expected to internalize the principle of a Home Scientist, that is, to give back to the community from which they draw, for sustainable development. This is a major contribution of Special studies in both developed and developing societies.

This can be concluded that special studies are an interdisciplinary field of knowledge and there is a lot of opportunity for women entrepreneurship. Women's entrepreneurship can make a particularly strong contribution to the economic well-being of the family and communities, country poverty reduction.

\section{References}

1. Agarwal V.K, "Initiative, Enterprise and Economic Choices in India", Munshiram Manoharial, New Delhi, 1975, p.82. 
2. Sharma R.A., "Entrepreneurial Change in Indian Industry" Sterling Publishers Pvt., Ltd., New Delhi, 1980 p.29.

3. Nandapurkar. G.G, "Small Farmers - A Study on their Entrepreneurial Behaviour", Metropolitan Book Company Pvt. Ltd., New Delhi, 1982, p.33.

4. Uddin Sami and Ziauddin Khairoowala. "Factors affecting Entrepreneurial growth; Entrepreneurship Development in India", Mittal Publications, New Delhi, 1989 Ed.

5. Pillai Dr N.C. and V. Anna. "The Entrepreneurial Spirit among Women" (A study of Kerala) Indian Management - Nov-Dec 1990.

6. Balasubramanya, "Reservation policy for small scale industry; Has it delivered the Good?", Economic and Political Weekly. Vol. XXVI, May. 2. 1995.

7. Rani, D. Lalitha, "Women Entrepreneurs", APH Publishing House, 1996 Ed. Rani in Vishakapatnam in 1996

8. Kaza P. Geetha. Nabard. "Women Entrepreneurs and Bank Credit Problems and Perspectives; Programme on Gender issue in Credit disseminations" BIRD August, 1996.pp 26-29.

9. Charumathi, B., "Women Entrepreneurs' Challenges and Prospects", The 32 Gangwar, S., Tripathy, I.P. and Mishra, A.K, "Scope for Women in MadhyaPradesh", The Indian journal of commerce, December, 1997 Vol. L, No.193,Part IV, pp. 249253.

10. Kamble, H.Y., "A Study of The SocioEconomic Background of Women Entrepreneurs of Belgaum Taluk", The Indian Journal of Commerce, December, 1997, Vol. L, No. 193, Part IV, pp. 229-242.
11. Gosh, "Women and Entrepreneurship in India", in Rububdra Kanungo (ed), Entrepreneurship and innovation, Sage Publishers. New Delhi. 1998.

12. Mathew, "Towards an Alternative Methodology for identifying Entrepreneurial potential in a Regional setting", National Seminar on Current trends in Entrepreneurship Research, Conducted by Entrepreneurship Development Institute. Ahmedabad. 1998.

13. Punitha $\mathrm{M}$, Sangeetha and $\mathrm{S}$ Padmavathi, "Women Entrepreneurs: Their Problems and Constraints", Indian Journal of Labour Economics. 1999,Vol. 42, No. 4, pp. 701-706.

14. Kalyani, W. and Chandralekha, K. "Association Between Socio-Economic Demographic Profile and Involvement of Women Entrepreneurs in Their Enterprise Management", The Journal of Entrepreneurship, 2002, Vol.11 No.2, pp. 220-247.

15. Ganesan, R., Kaur, D. and Maheshwari, R.C. "Women Entrepreneurs: Problems and Prospects", The Journal of Entrepreneurship, 2002, Vol. 11 No.1, pp. 75-93.

16. Nirmala Karuna D'Cruz, “Constraints on Women Entrepreneurship Development in Kerala: An analysis of familial, social, and psychological dimensions", Women Studies in India. 2003, pp-1-46.33.

17. Neeta Anand, "Working Women: Issues and Problem 34

18. Sudha $\mathrm{S}$ and Kasilingam R, "Personality traits and Entrepreneurial Characteristics of Women Entrepreneurs in Tamil Nadu", Journal of Management and Entrepreneurship, October-December, 2009, Vol. II, Issue IV.

19. Sankaran A, "Trends and Problems of Rural Women Entrepreneurs in India", 
Southern Economist, June, 2009, vol. 48, No. 4, pp. 11-12.

20. Subbulakshmi "Women entrepreneurs in Chennai Environ", Southern Economist, April, 2010, Vol.48, No.24, pp. 33-36.

21. Angayarkanni, "Problems of Women entrepreneurs in India", Southern Economist, February, 2010, Vol.48, No.19, pp. 44-46.

22. Dr Rana Zehra Masood,, "Emergence of women-owned businesses in Indiaan insight", 2011.Vroom, V. H. "Work and motivation". New York: Wiley. 1964 Hennig, M. and Jardim, A., "The Managerial Woman", Anchor Press/Doubleday, Garden City, New York, NY. 1975 Cliff, J. E. "Does one size fit all? Exploring the relationship between attitudes towards growth, gender, and business size". Journal of Business Venturing, 13(6), 1998, pp523-542.

23. Lefcourt, H. M. (Ed.). "Research with the locus of control constructs Vol. 1:Assessment methods. London": Academic Press. 1981. Druker, P.F, "Innovation and Entrepreneurship Practices and Principles", Heinemann, London, 1985, p. 41.35.
24. Mansfied, S, Richard, S, Mccleland, D.C, Spenser Lyle and Santiago Jose, Mc Ber and Co. "The identification and Assessment of Competencies and Other Personal Characteristics of Entrepreneurs in Developing Countries", Boston, 1987 pp. 136-142.

25. Breen J, Calvert $\mathrm{C}$ and Oliver $\mathrm{J}$, "Female Entrepreneurs in Australia: An Investigation of financial and family issues", Journal of Enterprising Culture, Vol.3, No. 4, 1995, pp. 445-461.

26. Kaza P. Geetha. Nabard. "Women Entrepreneurs and Bank Credit Problems and Perspectives; Programme on Gender issue in Credit disseminations" BIRD, August, 1997, pp 26-29.

27. Bandura, A. "Self-efficacy: The exercise of control". New York: Freeman. 1997. Finansdepartemenetet, "Egenforetagande Och Manna Fran Himlen" Entrepreneurial Society, DsSerien. 1997, p. 71.

28. Inman, K., "Women's resources in business start-up: a study of black and white women entrepreneurs", Doctoral Dissertation. 1997.

\section{How to cite this article:}

Deepa Indoria, Mani Ram and Solanki, R.L. 2019. Role of Education in Women Empowerment and Entrepreneurship. Int.J.Curr.Microbiol.App.Sci. 8(05): 72-79.

doi: https://doi.org/10.20546/ijcmas.2019.805.010 